Law and School Reform 
This page intentionally left blank 


\section{Law and School Reform}

Six Strategies for Promoting

Educational Equity

Edited by Jay P. Heubert

Yale University Press

New Haven and London 
Copyright $(\mathcal{O} 1999$ by Yale University. All rights reserved. This book may not be reproduced, in whole or in part, including illustrations, in any form (beyond that copying permitted by Sections 107 and 108 of the U.S. Copyright Law and except by reviewers for the public press), without written permission from the publishers.

Set in Adobe Garamond type by The Composing Room of Michigan, Inc. Printed in the United States of America.

\section{Library of Congress Cataloging-in-Publication Data}

Law and school reform : six strategies for promoting educational equity / edited by Jay P. Heubert.

p. $\quad \mathrm{cm}$.

Includes bibliographical references and index.

ISBN 978-0-300-08296-8

I. Educational equalization-United States. 2. Educational law and legislation-United States. 3. Education-United StatesFinance. 4. Minorities-Education-United States. 5. Special education-United States. 6. Educational change--United States. I. Heubert, Jay Philip.

$\mathrm{LC}_{213.2 .} \mathrm{L}_{39} \quad{ }^{1998}$
$379.2^{\prime} 6^{\prime} 0973-\mathrm{dc} 21 \quad 98-25572$

A catalogue record for this book is available from the British Library.

The paper in this book meets the guidelines for permanence and durability of the Committee on Production Guidelines for Book Longevity of the Council on Library Resources. 